\title{
PENGARUH KOMPRES HANGAT TERHADAP PENURUNAN DISMINORE PRIMER PADA REMAJA PUTRI (Di Pondok Pesantren Queen Al-Falah Ploso Mojo Kediri)
}

Lely Khulafa'ur Rosidah, S.ST.M.Kes ${ }^{1}$, Adelina Diah Permata Larasati ${ }^{2}$

Akademi Kebidanan Dharma Husada Kediri Jawa Timur

\begin{abstract}
ABSTRAK
Kompres hangat merupakan tindakan dengan memberikan kompres hangat yang bertujuan memenuhi kebutuhan rasa nyaman, mengurangi atau membebaskan nyeri, mengurangi atau mencegah terjadinya spasme otot dan memberikan rasa hangat.Disminore adalah nyeri pada daerah panggul akibat menstruasi dan produksi zat prostaglandin.Seringkali di mulai segera setelah mengalami menstruasi pertama atau menarce.Nyeri berkurang setelah menstruasi, namun pada beberapa wanita nyeri bisa terus dialami selama periode menstruasi.Tujuan penelitian ini adalah untuk mengetahui pengaruh kompres hangat terhadap penurunan disminore primer pada remaja putri di Pondok Pesantren Queen Al-falah Ploso Mojo Kediri.

Desain penelitian adalah pra-eksperimenta dengan menggunakan one group pre-testpost-test design.Populasinya adalah Semua Remaja putri yang mengalami disminore primer di pondok pesantren Queen Al-falah ploso mojo Kediri berjumlah 30 orang. Pengambilan Sampel menggunakan teknik total sampling sehingga seluruh populasi digunakan sampel. Variabel penelitian ini terdiri dari 2 variabel yaituIndependent Variable berupa kompres hangat dan Dependent Variable berupa penurunan disminore primer pada remaja putri. Pengumpulan data diperoleh menggunakanchecklist, pengolahan data melalui editing, coding, scoring dan tabulating. Untuk menguji adanya perbedaan dilakukan analisa uji Wilcoxon Match Pair Testdengan hasil Z sebesar -5,385.

Hasil penelitian menunjukkan skala nyeri disminore primer sebelum dikompres hangat dengan kategori nyeri berat, sebanyak 16 responden $(53,3 \%)$ dan nyeri sedang sebanyak 14 responden (46,7\%). Sedangkan skala nyeri disminore primer sesudah dikompres hangat terbanyak dengan kategori nyeri sedang sebanyak 17 responden (56,7\%) dan nyeri ringan sebanyak 13 responden (43,3\%).Dari uji Wilcoxon didapatkan hasil ada pengaruh penurunan disminore primer sebelum dan sesudah dilakukan kompres hangat pada remaja putri $(\sigma \leq 0,05)$.

Berdasarkan penelitian tersebut, dapat diketahui Ada perbedaan pengaruh penurunan disminore primer sebelum dan sesudah dilakukan kompres hangat pada remaja putri di Pondok Pesantren Queen Al-falah Ploso Mojo Kediri yaitu, yang mengalami nyeri disminore primer dengan kategori berat setelah dilakukan kompres hangat telah menurun menjadi kategori nyeri sedang dan nyeri ringan.
\end{abstract}

Kata Kunci : Kompres Hangat, Disminore Primer, Remaja. 


\section{PENDAHULUAN}

Masa remaja adalah masa transisi antara masa anak-anak ke masa dewasa. Remaja akan mengalami pubertas. Pubertas adalah masa awal pematangan organ seksual. Yang ditandai dengan pertumbuhan badan yang cepat, menstruasi pertama (menarche), perubahan psikis dan timbulnya ciri-ciri kelamin sekunder seperti timbulnya rambut pada daerah kemaluan dan pembesaran payudara (Andira, 2010 : 29).

Menarche adalah saat haid atau menstruasi yang datang pertama kali yang sebenarnya merupakan puncak dari serangkaian perubahan yang terjadi pada seorang remaja putri yang sedang menginjak dewasa dan sebagai tanda bahwa ia sudah mampu hamil (Andira, $2010: 31)$

Setelah mengalami menarche, wanita akan memulai kehidupan barunya dengan berawalnya siklus menstruasi. Tetapi banyak juga yang tidak mendapatkan informasi tentang menstruasi sebelumnya dari keluarga atau orang disekitarnya, sehingga remaja awal tersebut tidak terlalu menganggap penting tentang hal ini. Informasi tentang menstruasi pada remaja awal sangat diperlukan untuk kesiapan psikologis mereka.

Menstruasi atau yang kita kenal dengan istilah haid adalah kejadian alamiah yang terjadi pada wanita normal. Hal ini terjadi karena terlepasnya lapisan endometrium uterus. Haid biasanya terjadi setiap bulan ( dengan siklus setiap orang berbeda, ada yang 28 hari, ada pula yang kurang atau bahkan lebih dari itu ) antara usia remaja sampai menopause. Selama menstruasi, darah dan lapisan yang terbentuk pada dinding rahim mengalir keluar lewat vagina, termasuk juga sel telur yang mati karena tidak dibuahi oleh sperma (Andira, $2010: 30$ ).

Seiring terjadinya menstruasi banyak wanita yang mengalami masalah menstruasi, diantaranya adalah nyeri haid atau menstruasi. Dalam istilah medis, nyeri haid disebut disminore.

Dismenore yaitu rasa sakit saat haid yang dapat mengganggu aktifitas sehari-hari. Tidak setiap wanita memiliki skala nyeri haid yang sama, ada yang ringan, ada juga yang berat. Pada kondisi yang berat penderita bisa sampai pingsan karena menahan nyeri yang hebat, dan ada juga yang harus bed rest. Biasanya dismenore terjadi pada awal datangnya haid. Selama periode haid, uterus (rahim) mengalami kontraksi. Kadangkala pada saat uterus berkontraksi, penderita merasakan nyeri kram. Otot-otot pada uterus akan berkontraksi pada saat prostaglandin dihasilkan. Prostaglandin adalah zat kimia yang dihasilkan oleh dinding uterus. Sesaat sebelum terjadinya haid, kadar prostaglandin akan meningkat dan pada saat awal terjadinya haid, prostaglandin berada dalam kadar yang tinggi. Pada saat mulai terjadi haid maka kadar prostaglandin kemudian akan menurun. Hal inilah yang menyebabkan nyeri haid cenderung dirasakan berkurang setelah beberapa hari pertama terjadi haid (Nursewian, 2013)

Disminore sendiri memiliki 2 tipe, yaitu disminore primer dan disminore sekunder. Dikatakan disminore primer jika tidak ditemukan penyebab yang mendasarinya. Sementara itu, dikatakan disminore sekunder jika penyebabnya adalah kelainan kandungan. Disminore primer sering terjadi, kemungkinan lebih dari $50 \%$ perempuan mengalaminya dan $15 \%$ diantaranya mengalami nyeri yang hebat. biasanya disminore primer muncul pada masa remaja, yaitu sekitar 2-3 tahun setelah menstruasi pertama. Nyeri pada disminore primer diduga berasal dari kontraksi rahim yang dirangsang dari prostaglandin. Nyeri dirasakan semakin hebat ketika bekuan atau potongan jaringan dari lapisan rahim melewati serviks (leher rahim), 
terutama jika saluran serviksnya sempit. Faktor lainnya yang bisa memperburuk disminore adalah rahim yang menghadap kebelakang (retroversi), kurang berolahraga juga stres psikis atau stres sosial. Pertambahan umur dan kehamilan akan menyebabkan menghilangnya disminore primer. Hal ini diduga terjadi karena adanya kemunduran saraf rahim akibat penuaan dan hilangnya sebagian saraf pada akhir kehamilan. (Saraswati, $2010: 27-28$ )

Pada nyeri haid primer, tanda dan gejalanya adalah Terjadi pada usia yang masih relatif muda, timbul setelah terjadinya siklus haid yang teratur. Nyeri sering terasa sebagai kejang uterus. Nyeri timbul mendahului haid dan meningkat pada hari pertama atau kedua haid.

Disminore sekunder sering timbul pada usia 20 tahun. Disminore menyebabkan nyeri pada perut bagian bawah yang bisa menjalar ke punggung bagian bawah dan tungkai. Nyeri dirasakan sebagai kram yang hilangtimbul atau sebagai nyeri sebagai nyeri tumpul yang terus-menerus ada. Biasanya nyeri mulai timbul sesaat sebelum atau selama menstruasi, lalu mencapai puncaknya dalam waktu 24 jam dan setelah dua hari menghilang. (Saraswati, $2010: 29$ )

Di Indonesia angka kejadian disminore terdiri dari $54,89 \%$ disminore primer dan 9,36\% disminore sekunder. Biasanya gejala tersebut terjadi pada wanita usia produktif 6-12 bulan setelah mengalami haid pertama dan wanita yang belum pernah hamil. Pada tahun 2014 di Jakarta 76,6\% siswa tidak masuk sekolah karena nyeri haid. Di Surabaya pada tahun 2014 didapatkan $1,07 \%$ hingga $1,31 \%$ dari jumlah penderita datang kebagian kebidanan untuk konsultasi masalah nyeri haid. (Proverawati \& Misaroh, 2009 : 86)

Berdasarkan studi pendahuluan di Pondok pesantren Queen Al-falah ploso mojo Kediri pada tanggal 20 maret 2015 dari 10 santriwati yang diwawancarai, didapat $4(40 \%)$ santriwati yang mengalami disminore primer dan 6 ( 60 $\%$ ) santriwati tidak mengalami disminore primer.

Meskipun kejadian disminore cukup tinggi akan tetapi masih banyak yang belum tahu cara mengatasi disminore tersebut dan lebih memilih untuk tidak melakukan kegiatan apapun selama nyeri tersebut muncul. Pada dasarnya nyeri dapat diatasi dengan melakukan berbagai alternatif, baik secara farmakologi maupun non farmakologi.

Pengobatan agar dapat mengurangi rasa nyeri bisa diberikan obat anti peradangan non-steroid (misalnya ibuprofen, naproxen, asam mefenamat). Selain dengan obat-obatan, rasa nyeri juga bisa dikurangi dengan istirahat cukup, olahraga yang teratur (terutama berjalan), pemijatan, yoga, dan kompres hangat di daerah perut. (Saraswati,2010 :29)

Salah satu pengobatan non farmakologi yang mudah di lakukan yaitu kompres hangat. Terapi kompres hangat merupakan tindakan dengan memberikan kompres hangat yang bertujuan memenuhi kebutuhan rasa nyaman, mengurangi atau membebaskan nyeri, mengurangi atau mencegah terjadinya spasme otot dan memberikan rasa hangat. Aplikasi hangat dapat mengakibatkan dilatasi atau membuka aliran darah yang mengakibatkan relaksasi dari otot. Suhu panas diketahui bisa meminimalkan ketegangan otot. Akibatnya setelah otot-otot relaks, rasa nyeripun berangsur-angsur hilang (Nella, 2012).

Kompres hangat telah banyak digunakan untuk mengurangi berbagai nyeri. Misalnya pada keluhan nyeri atau sakit kepala, kaki kram dan nyeri akibat pembesaran rahim pada ibu hamil. Selain itu kompres hangat juga dapat digunakan untuk mengurangi nyeri pada leher yang kaku. Serta dapat digunakan 
untuk mengurangi nyeri pada kaki yang terkilir.

Dengan melihat latar belakang diatas, peneliti tertarik untuk melakukan penelitian yang berjudul "Pengaruh

\section{METODE}

Desain penelitian ini menggunakan pra-eksperimental dengan menggunakan one group pre-test-post-test design,.populasinya adalah semua remaja putri yang mengalami disminore primer di Pondok Pesantren Queen Alfalah Ploso Mojo Kediri, yang berjumlah 30 orang Dengan teknik total sampling didapatkan 30 responden.Variabel dalam penelitian ini terdapat dua variabel yaitu variabel independen dan dependen.Variabel independen yaitu kompres hangat dan variabel dependennya penurunan disminore primer pada remaja putri. Pengumpulan data menggunakan Check listyang diberikan kepada responden sebelum dilakukan kompres hangat dan sesudah dilakukan kompres hangatpada tanggal 5-16 Mei 2015. Pengolahan data menggunakan editing, coding, scoring, tabulating.Dengan analisa data menggunakan uji Wilcoxon Match Pairs Test
Kompres Hangat Terhadap Penurunan Disminore Primer pada remaja putri di Pondok Pesantren Queen Al-falah Ploso Mojo

Kediri” 


\section{HASIL}

Berdasarkan hasil uji statistik 2 variabel dengan menggunakan Wilcoxon Match pair Test menunjukkan hasil Z sebesar $-5,385$ dengan tingkat signifikansi $(\sigma)$ sebesar $0,000(\sigma \leq 0,05)$. Karena nilai $\sigma \leq 0,05$ maka $\mathrm{H} 0$ di tolak dan $\mathrm{H} 1$ diterima yang artinya ada pengaruh penurunan disminore primer sebelum dan sesudah dilakukan kompres hangat pada remaja putri.Kompres hangat berpengaruh dalam menurunkan nyeri disminore primer pada remaja putri di Pondok Pesantren Queen Al-falah Ploso Mojo Kediri. Hal ini ditunjukkan dengan kriteria skala nyeri sebelum dilakukan kompres hangat terdapat 16 orang $(53,3 \%)$ yang mengalami nyeri berat sedangkan setelah dilakukan kompres hangat tidak terdapat lagi responden yang mengalami nyeri berat.

Tabel 1 Analisa Perbedaan Pengaruh Penurunan Disminore Primer Sebelum dan Sesudah Dilakukan Kompres hangat Pada Remaja Putri Di Pondok Pesantren Queen Al-Falah Ploso Mojo Kediri.

\begin{tabular}{|c|c|c|c|c|c|c|c|c|c|c|}
\hline \multirow{2}{*}{\begin{tabular}{c} 
Skala nyeri \\
\multirow{2}{*}{$\begin{array}{c}\text { Disminore } \\
\text { primer }\end{array}$}
\end{tabular}} & \multicolumn{2}{|c|}{$\begin{array}{c}\text { Tidak } \\
\text { Nyeri }\end{array}$} & \multicolumn{2}{|c|}{ Ringan } & \multicolumn{2}{|c|}{ Sedang } & \multicolumn{2}{c|}{ Berat } & \multicolumn{2}{c|}{ Sangat Berat } \\
\cline { 2 - 11 } & F & $\%$ & F & $\%$ & F & $\%$ & F & $\%$ & F & $\%$ \\
\hline $\begin{array}{l}\text { Sebelum diberi } \\
\text { kompres hangat }\end{array}$ & 0 & 0 & 0 & 0 & 14 & 46,7 & 16 & 53,3 & 0 & 0 \\
\hline $\begin{array}{l}\text { Sesudah diberi } \\
\text { kompres hangat }\end{array}$ & 0 & 0 & 13 & 43,3 & 17 & 56,7 & 0 & 0 & 0 & 0 \\
\hline
\end{tabular}

\section{DISKUSI}

Hasil uji statistik yang dilakukan dengan uji Wilcoxon Match pair Test pada 30 responden yang dilakukan menggunakan computer menghasilkan nilai $\mathrm{Z}$ sebesar5.385 dengan nilai signifikan $(\sigma)$ sebesar 0,000 . Hal ini berarti nilai signifikansi nyeri disminore primer sebelum dan sesudah diberikan kompres hangat dengan tingkat kesalahan $(\sigma) 5 \%$ atau 0,05 sebesar $0,000(\sigma \leq 0,05)$. Dari hasil analisis, menunjukkan bahwa yang mengalami penurunan nyeri disminore primer ada 29 responden $(96,67 \%)$, yang mengalami nyeri tetap sebanyak 1 responden $(3,33 \%)$ dengan tingkat signifikansi $(\sigma)$ sebesar $0,000(\sigma \leq 0,05)$. Karena nilai $\sigma \leq 0,05$ maka $\mathrm{H} 0$ di tolak dan $\mathrm{H} 1$ diterima yang artinya ada pengaruh penurunan disminore primer sebelum dan sesudah dilakukan kompres hangat pada remaja putri.

Disminore primer yaitu disminore yang terjadi tanpa disertai adanya kelainan ginekologis. (Okparasta, 2008). Nyeri ini timbul sejak menstruasi pertama dan akan pulih sendiri dengan berjalannya waktu. Tepatnya saat hormon tubuh lebih stabil atau perubahan posisi rahim setelah menikah atau melahirkan (Aulia, 2009 : 89). Untuk mengatasi disminore primer salah satunya dapat menggunakan kompres hangat. Kompres hangat adalah memberikan rasa hangat untuk memenuhi kebutuhan rasa nyaman, mengurangi atau membebaskan nyeri, mengurangi atau mencegah spasme otot dan memberikan rasa hangat pada daerah tertentu (Nella, 2012). Kompres hangat sendiri memiliki manfaat untuk melancarkan peredaran darah sehingga dapat mengurangi rasa nyeri pada daerah tertentu yang disebabkan karena spasme otot. Dalam hal ini kompres hangat yang digunakan yaitu kompres hangat kering dengan buli-buli panas. Kompres hangat ini diberikan selama 20 menit dengan suhu $50^{\circ} \mathrm{C}-60^{\circ} \mathrm{C}$. 
Menurut responden selama diberikan kompres hangat responden merasa nyaman dan rasa nyeri disminore berangsur berkurang sehingga responden dapat beraktifitas seperti biasa. Mereka yang mengalami disminore biasanya mengalami nyeri ini pada 24 jam sebelum terjadi menstruasi dan dapat terasa selama 24-36 jam. Kram ini dirasakan terutama pada perut bagian bawah dan menjalar hingga ke punggung. Beberapa responden yang mengalami disminore berat bisa sampai muntah dan diare.

Dari hasil penelitian yang paling memperlihatkan perubahan yaitu nyeri disminore primer sebelum diberikan kompres hangat dan sesudah diberikan kompres hangat memiliki perubahan yang signifikan.

Gejala-gejala yang timbul dari disminore primer sendiri meliputi : Disminore primer biasanya muncul 6-12 bulan sesudah menarche saat siklus ovulasi dimulai. Nyeri perut bagian bawah yang seperti kejang biasanya mulai beberapa jam sesudah menstruasi dan jarang berlangsung lebih dari 72 jam. Gejalagejala sistemik dapat menyertai nyeri uterus pada lebih dari $50 \%$ pasien. Gejalagejala ini termasuk mual dan muntah, kelelahan, diare, nyeri punggung bawah, dan nyeri kepala. Pada kasus yang berat, juga dapat terjadi kegelisahan, pusing dan sinkop (Saraswati, $2010: 27$ )

Sebagian responden mengatakan bahwa mereka merasakan nyeri disminore

\section{SIMPULAN}

Berdasarkan hasil penelitian dan analisa data yang dilakukan maka dapat ditarik kesimpulanAda pengaruh penurunan disminore primer sebelum dan sesudah dilakukan kompres hangat pada remaja putri di Pondok Pesantren Queen Al-falah Ploso Mojo Kediri yaitu, yang mengalami biasanya 1-2 hari sebelum terjadi menstruasi, ada juga yang mengatakan bahwa ia mengalami nyeri pada hari pertama menstruasi dan akan hilang pada keesokan harinya. Responden yang mengalami nyeri disminore primer hingga tingkat nyeri berat biasanya berlangsung lebih lama dan biasanya mereka memilih untuk beristirahat di asrama dan tidak melakukan aktifitas apapun. Nyeri disminore primer ini dirasakan sebagai kram yang hilang timbul. Pertambahan umur dan kehamilan akan menyebabkan menghilangnya nyeri disminore primer. Hal ini diduga terjadi karena adanya kemunduran saraf rahim akibat penuaan dan hilangnya sebagian saraf pada akhir kehamilan atau saat melahirkan.

Jadi dari data di atas dapat di simpulkan bahwa terdapat perubahan yang signifikan pada nyeri disminore primer antara sebelum diberikan kompres hangat dan sesudah diberikan kompres hangat. Tingkat nyeri disminore primer pada responden yang mengalami nyeri berat telah menurun menjadi tingkat nyeri sedang bahkan nyeri ringan. Setelah dilakukan penelitian ini responden yang mengalami disminore tidak lagi berfikiran untuk tetap mengonsumsi obat-obatan melainkan lebih memilih untuk menggunakan alternatif lain yang lebih aman dan tidak menimbulkan efek samping.

nyeri disminore primer dengan kategori berat yang awalnya berjumlah 16 orang $(53,3 \%)$ dan yang mengalami nyeri sedang berjumlah 14 orang $(46,7 \%)$ setelah dilakukan kompres hangat telah menurun menjadi

kategori nyeri sedang sejumlah 17 orang $(56,7 \%)$ dan nyeri ringan sejumlah 13 orang $(43,3 \%)$. 


\section{DAFTAR PUSTAKA}

Andira.Dita, 2010.Seluk-Beluk Kesehatan Reproduksi Wanita.Yogyakarta :A Pius Books.

Aulia, 2009.Kupas Tuntas Menstruasi dari A sampai Z. Yogyakarta: Millestone

Perry GA \& Potter AP. 2005. Patofisiologi: Konsep Proses \& Praktek (Fundamental of Nursing: Consept Process and Practice). Eds Ester, M. Yulianti D \& Parulian I, vol , edk 4, EGK. Jakarta

Proverawati.Atikah. 2009. Menarche Menstruasi Pertama Penuh Makna. Yogyakarta: Nuha Media

Sylvia Saraswati. 2010. Mencegah \& Mengobati 52 Penyakit yang Sering Diderita Perempuan. Katahati.

Tarwoto.2010. Kesehatan Remaja Problem \& Solusinya. Jakarta: Salemba Medika 
